\author{
Marta Maciejasz-Świątkiewicz, Krzysztof Ćwieląg \\ Uniwersytet Opolski \\ e-mails: marta.ms@uni.opole.pl; kcwielag@uni.opole.pl
}
ANALIZA WSKAŹNIKOWA
JAKO METODA OCENY SKUTECZNOŚCI
AUDYTU WEWNĘTRZNEGO W RACJONALIZOWANIU GOSPODARKI FINANSOWEJ JEDNOSTEK SAMORZĄDU TERYTORIALNEGO

\title{
RATIO ANALYSIS AS A METHOD OF EVALUATING THE EFFECTIVENESS OF INTERNAL AUDIT \\ IN RATIONALIZING THE FINANCIAL MANAGEMENT OF LOCAL GOVERNMENT UNITS
}

DOI: $10.15611 /$ nof.2016.1.05

JEL Classification: H72

\begin{abstract}
Streszczenie: Gospodarowanie finansami samorządowymi jest procesem decyzyjnym, którego ważnym elementem staje się informacja. Aby decyzje były racjonalne, nie mogą być przypadkowe i podejmowane w sposób intuicyjny. Powinny opierać się na wiarygodnych i odpowiednio przetworzonych informacjach. Jednym z narzędzi oceny skuteczności działania JST jest analiza ekonomiczna, a szczególnie analiza wskaźnikowa. Z kolei audyt wewnętrzny jest działalnością niezależną i obiektywną, której celem jest wspieranie kierownika jednostki w realizacji celów i zadań przez systematyczną ocenę kontroli zarządczej oraz czynności doradcze. W dużej mierze audyt wewnętrzny jest postrzegany jako narzędzie zarządzania, podczas gdy jego sens ekonomiczny powinien być znacznie szerszy i skupiać się na racjonalizacji gospodarki finansowej. Niniejszy artykuł stanowi próbę oceny tego, czy audyt wewnętrzny prowadzony w gminach idzie w parze z osiąganiem korzystnych wartości wskaźników ekonomicznych, a tym samym racjonalizacją gospodarki finansowej JST. W tym celu przeprowadzono komparatywną analizę wskaźnikową gmin województwa opolskiego, które prowadzą audyt wewnętrzny i go nie prowadzą. Celem artykułu jest odpowiedź na pytanie, czy gminy, które prowadzą audyt wewnętrzny, osiągają lepsze wyniki ekonomiczne niż gminy, które audytu nie prowadzą.
\end{abstract}

Słowa kluczowe: analiza wskaźnikowa, audyt wewnętrzny, racjonalizacja gospodarki finansowej, jednostki samorządu terytorialnego.

Summary: Information becomes a more and more important element of the decision-making process in municipal financial management. To make these decisions reasonable, they cannot be random and taken intuitively. They should be based on reliable and properly transformed information. This article is an attempt to find whether an internal audit conducted in 
municipalities accompanies the achievement of favorable values of economic indicators. For this purpose, there was conducted a comparative analysis of the indicators for municipalities that use and do not use an internal audit. This article aims to answer the question whether municipalities that use the internal audit achieve better economic results than municipalities that do not conduct an audit.

Keywords: ratio analysis, internal audit, financial management rationalization, local government units.

\section{Wstęp}

Jednostki samorządu terytorialnego (JST) jako podmioty funkcjonujące na rynku i prowadzące własną gospodarkę finansową (podmioty gospodarujące) stają przed wieloma złożonymi problemami, wynikającymi ze zmienności otoczenia i ryzyka, które nieodłącznie towarzyszy ich działalności. Problemy te wymagają od samorządów dokonywania racjonalnych wyborów i podejmowania optymalnych decyzji z punktu widzenia funkcjonowania jednostki. Gospodarowanie finansami samorządowymi jest procesem decyzyjnym, którego ważnym elementem staje się informacja. Aby decyzje były racjonalne, nie mogą być przypadkowe i podejmowane w sposób intuicyjny. Powinny opierać się na wiarygodnych i odpowiednio przetworzonych informacjach (danych finansowo-księgowych), pochodzących z systemu rachunkowości budżetowej i sprawozdawczości finansowej jednostki. Trafność informacji rozstrzyga o skuteczności i ekonomiczności podejmowanych działań oraz o stopniu realizacji zadań postawionych przed JST [Dylewski, Filipiak, Gorzałczyńska-Koczkodaj 2004, s. 7]. Związek między audytem wewnętrznym a stopniem racjonalizacji gospodarki finansowej JST znajduje odzwierciedlenie w kondycji finansowej tych jednostek. Ustalona została ona na podstawie pomiaru o charakterze ilościowym dokonanego za pomocą wybranych wskaźników finansowych.

Audyt wewnętrzny to działalność niezależna i obiektywna, której celem jest wspieranie kierownika jednostki w realizacji celów i zadań przez systematyczną ocenę kontroli zarządczej oraz czynności doradcze [Ustawa z dnia 27 sierpnia 2009 r...., art. 272, ust. 1]. Audyt w JST jest prowadzony obligatoryjnie, jeśli kwota dochodów i przychodów lub wydatków i rozchodów ujęta w uchwale budżetowej przekroczyła wysokość $40 \mathrm{mln}$ zł. Audyt może być również wprowadzony dobrowolnie, na podstawie decyzji kierownika jednostki [Ustawa z dnia 27 sierpnia 2009 r...., art. 274, ust. 3-4].

W dużej mierze audyt wewnętrzny jest postrzegany jako narzędzie zarządzania, podczas gdy jego sens ekonomiczny powinien być znacznie szerszy i skupiać się na racjonalizacji gospodarki finansowej. Takie podejście wynika bezpośrednio z zasady racjonalizacji gospodarki budżetowej, zawartej w ustawie o finansach publicznych, zgodnie $\mathrm{z}$ którą wydatki publiczne powinny być dokonywane w sposób celowy i oszczędny, z zachowaniem zasad uzyskiwania najlepszych efektów z da- 
nych nakładów oraz optymalnego doboru metod i środków służących osiągnięciu założonych celów [Ustawa z dnia 27 sierpnia 2009 r...., art. 44, ust. 3, pkt 1]. Audyt wewnętrzny dzięki kontroli sprawowanej nad przestrzeganiem ustawowych zasad oraz dzięki możliwości formułowania wytycznych do realizacji w przyszłości ma niewątpliwie ogromny potencjał jako narzędzie usprawniania gospodarki finansowej JST. To, w jakim stopniu potencjał ten będzie wykorzystany, zależy od tego, w jaki sposób audyt postrzegany jest przez kierownictwo jednostki oraz na ile wytyczne formułowane przez audytora znajdą odzwierciedlenie w praktyce.

Celem artykułu jest próba oceny funkcjonowania audytu wewnętrznego jako instrumentu wspomagającego racjonalną gospodarkę finansową JST poprzez odpowiedź na pytanie, czy gminy, które prowadzą audyt wewnętrzny, osiągają lepsze wyniki ekonomiczne niż gminy, które audytu nie prowadzą. Jedną z metod oceny skuteczności audytu wewnętrznego w tym zakresie jest analiza wskaźnikowa. Należy postawić pytanie, czy audyt wewnętrzny przekłada się na poprawę samorządowej gospodarki finansowej i co na to wskazuje? W artykule podjęto próbę określenia oddziaływania audytu wewnętrznego na ewentualną poprawę (lub jej brak) podstawowych wskaźników świadczących o zasobności, potencjale i bezpieczeństwie finansowym jednostki, na podstawie których można wnioskować o racjonalności lub nieracjonalności prowadzonej gospodarki finansowej. W związku z tym jako metodę badań przyjęto analizę porównawczą wybranych wskaźników struktury budżetu i sytuacji (kondycji) finansowej dla wyodrębnionych gmin z terenu województwa opolskiego, które prowadzily audyt wewnętrzny lub które go nie prowadziły. Uprawdopodobniono pozytywne oddziaływanie audytu wewnętrznego na poprawę samorządowej gospodarki finansowej wśród gmin prowadzących audyt w porównaniu z tymi, w których nie został on wprowadzony.

\section{Znaczenie analizy wskaźnikowej dla oceny efektywności i skuteczności działania JST}

Ocena skuteczności działania JST może być dokonywana z wykorzystaniem różnych narzędzi. Jednym z nich jest analiza ekonomiczna, a szczególnie analiza wskaźnikowa. Głównym celem analizy ekonomicznej jest ocena działalności prowadzonej przez JST, która daje podstawy do podejmowania decyzji operacyjnych, inwestycyjnych i dotyczących źródeł finansowania samorządu oraz pozwala na racjonalne wykorzystanie publicznych zasobów finansowych. Ocenie podlega przede wszystkim efektywność realizowanych przez samorząd terytorialny zadań i racjonalność wydatkowanych na te zadania środków publicznych.

Kluczową rolę w ramach analizy ekonomicznej odgrywa analiza finansowa ${ }^{1}$. Dotyczy ona całokształtu finansowych aspektów funkcjonowania JST [Dylewski

\footnotetext{
${ }^{1} \mathrm{~W}$ ramach analizy ekonomicznej, obok finansowej, wyodrębnia się również analizę strategiczną i techniczno-ekonomiczną. Za: [Dudycz, Wrzosek 2000, s. 11].
} 
2003, s. 37-45], w tym przede wszystkim gospodarki finansowej jednostki, obejmującej: dochody, przychody, wydatki i rozchody, przepływy pieniężne i płynność. Analiza finansowa zajmuje się badaniem stanu i rozwoju finansów samorządowych, jak również analizą i diagnozą finansowych skutków podejmowanych działań i realizowanych przez samorząd zadań. Pozwala na przeprowadzenie diagnozy sytuacji finansowej ze wskazaniem na kształtowanie się przyszłych wyników finansowych osiąganych przez jednostkę (prognoza), co wspomaga proces racjonalnego gospodarowania finansami samorządowymi.

Na podstawie prowadzonej analizy finansowej, która dotyczy funkcjonowania JST w przeszłości, obecnie i w przyszłości, komórki decyzyjne samorządu uzyskują najważniejsze informacje dotyczące: (1) ogólnej sytuacji finansowej jednostki (w ujęciu syntetycznym) i czynników ją kształtujących, (2) oceny działalności finansowej w zakresie dostarczania dóbr i usług pod kątem: kosztów i korzyści, poziomu realizowanych wydatków i dochodów czy czynników kształtujących ten poziom, (3) kierunków poprawy efektywności ekonomicznej przebiegających w jednostce procesów i realizowanych zadań, (4) budowy wariantów decyzyjnych (scenariuszy działania) wraz z symulacją ich skutków dla budżetu jednostki (pozytywne i negatywne skutki decyzji), (5) stanu majątku samorządowego i efektów jego wykorzystania [Dylewski, Filipiak, Gorzałczyńska-Koczkodaj 2010, s. 33-34].

Dla prowadzenia przez JST racjonalnej gospodarki finansowej istotna jest przede wszystkim wewnętrzna analiza finansowa, która przygotowywana jest na potrzeby wewnętrzne jednostki. Jej cel to wspomaganie procesów podejmowania decyzji, dokonywanie oceny efektywności realizacji zadań, wskazywanie na obszary, gdzie mogą wystąpić usprawnienia prowadzonych działań i realizowanych zadań. Stanowi ona również punkt wyjścia dla procesów restrukturyzacyjnych, rozwiązywania zaistniałych problemów i eliminowania przyczyn ich powstawania. Wewnętrzna analiza finansowa potwierdza lub nie sprawność i efektywność gospodarowania publicznymi zasobami finansowymi (zgodnie z zasadami racjonalnej gospodarki finansowej) oraz możliwości inwestycyjne i rozwojowe samorządu terytorialnego. Dotyczy zwykle wybranych obszarów działalności jednostki samorządowej, jest bardziej szczegółowa, wykonywana w sposób systematyczny i ciągły. Dlatego też wewnętrzną analizę finansową należy uznać za szczególnie użyteczną z punktu widzenia JST jako podmiotu gospodarującego, który działa w zmiennym otoczeniu i podejmuje decyzje.

$\mathrm{Z}$ punktu widzenia problematyki racjonalizowania samorządowej gospodarki finansowej szczególnego znaczenia nabiera analiza wskaźnikowa struktury budżetu i sytuacji finansowej (kondycji finansowej) JST. Dla racjonalnego wydatkowania środków publicznych ważne jest, jaką bazą dochodową dysponują JST (jej stabilność, struktura wewnętrzna). Dochody budżetowe stanowią o zasobności JST i pozwalają finansować zadania samorządu. Analiza ogólna dochodów sprowadza się do podziału dochodów na bieżące i majątkowe, co znajduje odzwierciedlenie w możliwościach finansowania przez samorządy zadań bieżących i zadłużenia (obsługa 
długu), jak również zadań inwestycyjnych [Ustawa z dnia 27 sierpnia 2009 r...., art. 235 i art. 236]. Spośród wymienianych w literaturze miar struktury dochodów [Dylewski, Filipiak, Gorzałczyńska-Koczkodaj 2004, s. 97-110; Dylewski, Filipiak, Gorzałczyńska-Koczkodaj 2010, s. 74-89] najbardziej użytecznymi przy prowadzeniu racjonalnej gospodarki finansowej przez JST są wskaźniki analizy dochodów własnych ${ }^{2}$, dotacji celowych i subwencji ogólnej oraz wskaźniki analizy dochodów według układu zadań.

Z kolei przy analizie strukturalnej wydatków niezwykle istotna jest ich struktura rodzajowa na realizację zadań samorządowych, gdyż realizacja zadań stanowi przedmiot podstawowych ocen i analiz dokonywanych w JST. Do analizy struktury rodzajowej wydatków można wykorzystać wskaźniki ogólnej struktury wydatków budżetowych (bieżących i majątkowych) oraz struktury rodzajów wydatków według układu osobowego i rzeczowego. Wskaźniki te umożliwiają określenie głównych kierunków wydatkowania środków finansowych z punktu widzenia klasyfikacji rodzajowej wydatków i układu realizowanych zadań (przedsięwzięć). Ponadto analiza zmian i dynamiki poszczególnych rodzajów wydatków pozwala na przeprowadzenie oceny i podjęcie niezbędnych działań racjonalizujących w zakresie planowania wydatków, ich rodzajów i struktury (z uwzględnieniem wsparcia ze środków bezzwrotnej pomocy zagranicznej dla JST).

Analiza finansowa prowadzona w JST umożliwia poznanie zjawisk ekonomiczno-finansowych, przyczyn i uwarunkowań ich powstawania, rozwoju, skutków wywieranych przez nie w przyszłości, wzajemnych powiązań i interakcji. Dzięki tym informacjom organy samorządowe (decydenci) mają możliwość zapoznania się z sytuacją finansową JST i mogą aktywnie wpływać, poprzez podejmowane działania, na kształt samorządowej gospodarki finansowej. Informacje pochodzące $\mathrm{z}$ analizy finansowej tworzą podstawę dla podejmowania optymalnych decyzji i warunkują racjonalną gospodarkę finansową samorządu terytorialnego.

Wnioski pochodzące z przeprowadzonej analizy finansowej pozwalają na ocenę stopnia realizacji celów działalności samorządu terytorialnego (skuteczność), jak również służą ocenie poziomu realizacji i jakości wykonywanych zadań (efektywność), które ujęte zostały w budżecie zadaniowym (BZ) czy w wieloletniej prognozie finansowej (WPF). W toku wnioskowania analitycznego, opierając się na ustalonych odchyleniach, poszukuje się przyczyn ich wystąpienia i czynników, które na nie wpłynęły. Prowadzi to do przyjęcia przez samorząd właściwego kierunku działania, umacnia korzystne tendencje lub zmierza do przywrócenia stanu równowagi gospodarki finansowej. Analiza finansowa oddziałuje na proces podejmowania dobrych decyzji w samorządzie, co skutkuje racjonalizowaniem gospodarki finansowej.

\footnotetext{
${ }^{2}$ Dochody własne obejmują klasyczny katalog ich źródeł zgodnie z ustawą o dochodach jednostek samorządu terytorialnego [Ustawa z 13 listopada 2003 r....] oraz udziały w podatkach PIT i CIT stanowiących dochód budżetu państwa.
} 
Oczywiście, przeprowadzając analizę finansową, korzysta się zwykle z wybranych wskaźników, które są najważniejsze dla kierownictwa jednostki i najwięcej wnoszą z punktu widzenia badanego obszaru gospodarki finansowej. Dlatego kluczowy jest odpowiedni dobór wskaźników pod kątem analizowanego obszaru gospodarki finansowej, który ma być racjonalizowany. Przetwarzaniem informacji i doborem wskaźników użytecznych dla kierownika JST w zakresie usprawnienia funkcjonowania jednostki, w tym racjonalizowania jej gospodarki finansowej, zajmuje się m.in. audyt wewnętrzny. Nie można oceniać prowadzonej gospodarki finansowej i wpływać na jej poprawę z pominięciem analizy finansowej, która jest punktem wyjścia do takiej oceny. Ponadto analiza ta stanowi podstawę dla działań realnych, znajdujących odzwierciedlenie w faktach, a nie działań intuicyjnych, opartych na subiektywnym odbiorze rzeczywistości.

\section{Analiza różnic międzygrupowych gmin prowadzących audyt wewnętrzny i go nieprowadzących}

Dla zobrazowania kierunków oddziaływania audytu wewnętrznego na poprawę efektywności i skuteczności funkcjonowania gospodarki finansowej JST przeprowadzono komparatywną analizę wskaźnikową gmin, które prowadzą audyt wewnętrzny i go nie prowadzą (tab. 1). W tym celu spośród gmin $\mathrm{z}$ obszaru województwa opolskiego wybrano wszystkie, które prowadziły obligatoryjnie audyt wewnętrzny (tj. 20 gmin, które poddano również badaniom ankietowym), oraz dla zachowania proporcji taką samą liczbę gmin, które nie prowadziły audytu wewnętrznego, gdyż nie przekroczyły ustawowego progu dotyczącego wielkości wykonanego budże$\mathrm{tu}^{3}$. Dla wnioskowania pożądane byłoby, gdyby badana próba była większa, jednak w obrębie województwa opolskiego nie jest to możliwe, ponieważ tylko 20 wymienionych w tab. 1 gmin prowadziło audyt wewnętrzny. Rozszerzenie badania na gminy $\mathrm{z}$ innych województw byłoby wysoce uzasadnione w przypadku porównań regionalnych czy próby dokonania analizy o zasięgu krajowym. W przypadku JST pozostałych szczebli, tj. powiatów i samorządu województwa opolskiego, przeprowadzenie analizy porównawczej w ogóle nie było możliwe, ponieważ wszystkie te jednostki prowadziły audyt wewnętrzny.

Wyselekcjonowane gminy poddano analizie wskaźnikowej ${ }^{4} \mathrm{w}$ celu oceny głównych obszarów samorządowej gospodarki finansowej (strona dochodowa i wydat-

\footnotetext{
${ }^{3}$ Pod uwagę wzięto dwadzieścia gmin z terenu Opolszczyzny, które nie miały obowiązku prowadzenia audytu wewnętrznego i faktycznie go nie prowadziły. Jednocześnie kwota zrealizowanych przez nie wydatków budżetowych była bliska, ale nie osiągnęła ustawowego progu $40 \mathrm{mln}$ zł.

${ }^{4}$ Selekcję gmin i obliczenia wybranych wskaźników finansowych przeprowadzono na podstawie danych pochodzących z RIO w Opolu, dotyczących sprawozdań z realizacji budżetów gmin, powiatów i budżetu województwa samorządowego z terenu Opolszczyzny w latach 2010-2013. Por. www. rio.opole.pl - zakładki: Działalność RIO/Działalność analityczna/Działalność analityczna w 2014 r./ Działalność analityczna w 2013 r./Działalność analityczna w 2012 r./Działalność analityczna w 2011 r.
} 
Tabela 1. Gminy województwa opolskiego poddane analizie, w których jest prowadzony audyt wewnętrzny i w których nie jest on prowadzony

\begin{tabular}{|c|c|}
\hline $\begin{array}{c}\text { Gminy prowadzące audyt wewnętrzny - } \\
\text { kwota wydatków budżetowych } \\
\text { przekroczyła } 40 \mathrm{mln} \mathrm{zł}\end{array}$ & $\begin{array}{c}\text { Gminy nieprowadzące audytu wewnętrznego - } \\
\text { kwota wydatków budżetowych } \\
\text { od } 23 \text { do } 40 \text { mln zł }\end{array}$ \\
\hline Brzeg & Biała \\
\hline Dobrzeń Wielki & Bierawa \\
\hline Głubczyce & Byczyna \\
\hline Głuchołazy & Dąbrowa \\
\hline Gogolin & Dobrodzień \\
\hline Grodków & Głogówek \\
\hline Kędzierzyn-Koźle & Kietrz \\
\hline Kluczbork & Komprachcice \\
\hline Krapkowice & Korfantów \\
\hline Lewin Brzeski & Leśnica \\
\hline Namysłów & Niemodlin \\
\hline Nysa & Paczków \\
\hline Olesno & Popielów \\
\hline Opole & Praszka \\
\hline Otmuchów & Prószków \\
\hline Ozimek & Rudniki \\
\hline Prudnik & Skarbimierz \\
\hline Strzelce Opolskie & Tarnów Opolski \\
\hline Wołczyn & Turawa \\
\hline Zdzieszowice & Zawadzkie \\
\hline$N=20$ & $N=20$ \\
\hline
\end{tabular}

Źródło: opracowanie własne.

kowa), w których audyt wewnętrzny mógł przełożyć się na racjonalność gospodarowania. W związku z tym podjęto próbę określenia oddziaływania funkcjonującego w gminach audytu wewnętrznego na ewentualną poprawę (lub jej brak) podstawowych wskaźników, odzwierciedlających zasobność, potencjał i bezpieczeństwo finansowe tych jednostek, na podstawie których można wnioskować o prowadzeniu racjonalnej lub nieracjonalnej gospodarki finansowej przez badane podmioty. Do przeprowadzenia analizy wybrano kilka podstawowych wskaźników, które posłużyły zbadaniu w poszczególnych gminach: ich sytuacji dochodowej i wydatkowej, stopnia pokrycia wydatków osiąganymi dochodami, samodzielności wydatkowej, ogólnego zadłużenia i całkowitej zdolności do rozwoju (tab. 2). 
Tabela 2. Podstawowe wskaźniki analizy finansowej zastosowane przy badaniu gmin

\begin{tabular}{|c|c|c|c|}
\hline Lp. & \multicolumn{3}{|r|}{ Rodzaj wskaźnika } \\
\hline 1 & $\mathbf{W D W}=\mathrm{DW} / \mathrm{D} \times 100$ & 6 & $\mathbf{W W D}=\mathrm{DW} / \mathrm{W} \times 100$ \\
\hline 2 & $\mathbf{W D C}=\mathrm{DC} / \mathrm{D} \times 100$ & 7 & $\mathbf{W S W}=(\mathrm{DW}+\mathrm{SO}) / \mathrm{D} \times 100$ \\
\hline 3 & $\mathbf{W S O}=\mathrm{SO} / \mathrm{D} \times 100$ & 8 & $\mathbf{W Z O}=\mathrm{ZO} / \mathrm{D} \times 100$ \\
\hline 4 & $\mathbf{W W B}=\mathrm{WB} / \mathrm{W} \times 100$ & 9 & \\
\hline 5 & $\mathbf{W W M}=\mathrm{WM} / \mathrm{W} \times 100$ & & $\mathbf{W C R}=\sum_{t=1}\left(\mathrm{DB}_{\mathrm{t}}-\mathrm{WB}_{\mathrm{t}}+\mathrm{DM}_{\mathrm{t}}\right) / \sum_{t=1} \mathrm{D}_{\mathrm{t}} \times 100$ \\
\hline
\end{tabular}

Objaśnienia: WDW - wskaźnik udziału dochodów własnych w dochodach ogółem; DW - dochody własne ogółem; D - dochody budżetu ogółem; WDC - wskaźnik udziału dotacji celowych ogółem w dochodach ogółem; DC - dotacje celowe ogółem; WSO - wskaźnik udziału subwencji ogólnej w dochodach ogółem; SO - subwencja ogólna; WWB - wskaźnik ogólnej struktury wydatków bieżących w wydatkach ogółem; WB - wydatki bieżące; W- wydatki budżetu ogółem; WWM - wskaźnik ogólnej struktury wydatków majątkowych w wydatkach ogółem; WM - wydatki majątkowe; WWD - wskaźnik pokrycia wydatków ogółem dochodami własnymi; WSW - wskaźnik samodzielności wydatkowej; WZO - wskaźnik ogólnego zadłużenia; ZO - zobowiązania ogółem; WCR - wskaźnik całkowitej zdolności do rozwoju jednostki dla okresu $n$ lat; $\mathbf{D B}_{\mathbf{t}}-$ dochody bieżące w danym roku $t$; $\mathbf{W B}_{\mathbf{t}}$ - wydatki bieżące w danym roku $t$; $\mathbf{D M}_{\mathbf{t}}$ - dochody majątkowe w danym roku $t ; \mathbf{D}_{\mathbf{t}}-$ dochody ogółem w danym roku $t$.

Źródło: opracowanie własne.

Wprawdzie za pomocą analizy wybranych wskaźników finansowych nie można w sposób jednoznaczny wykazać bezpośredniego związku przyczynowo-skutkowego dotyczącego przełożenia audytu wewnętrznego na poprawę gospodarki finansowej (zwykle audyt współwystępuje z innymi działaniami i instrumentami w tym zakresie), niemniej możliwe jest określenie pewnych korzystnych lub niekorzystnych tendencji zmian w obszarze dochodów i wydatków budżetowych gmin, które prowadzą audyt wewnętrzny lub go nie prowadzą.

Dla zobrazowania i dokonania oceny sytuacji dochodowej gmin posłużono się wskaźnikami udziału dochodów własnych, dotacji celowych i subwencji ogółem w dochodach budżetu gminy ogółem. Wskaźniki te świadczą przede wszystkim o niezależności finansowej jednostki i przedstawiają jej potencjał finansowy. Wraz ze wzrostem niezależności gmin od budżetu państwa rośnie ich potencjał finansowy i możliwości realizacji zadań samorządu gminnego. Sytuację taką można uznać za jeden $\mathrm{z}$ wymiernych efektów racjonalnie prowadzonej przez gminy gospodarki finansowej ${ }^{5}$.

Wskaźnik udziału dochodów własnych gminy w dochodach budżetu ogółem (WDW) odzwierciedla jej zasobność, potencjał finansowy i samodzielność w kreowaniu oraz generowaniu dochodów własnych. Wyższa wartość tego wskaźnika

\footnotetext{
${ }^{5}$ Przy obliczeniach wskaźników finansowych wykorzystano program do obróbki danych statystycznych STATISTICA.
} 
świadczy o faktycznej niezależności finansowej gminy od zewnętrznych źródeł finansowania i większym bezpieczeństwie finansowym, co przekłada się na zwiększenie możliwości realizacyjnych zadań jednostki. W gminach, które prowadziły audyt wewnętrzny, wskaźnik udziału dochodów własnych w dochodach budżetu ogółem (WDW) w latach 2010-2013 kształtował się na poziomie zdecydowanie wyższym aniżeli w gminach, które audytu wewnętrznego nie prowadziły. Może to potwierdzać słuszność założenia o korzystnym oddziaływaniu audytu wewnętrznego na wzrost niezależności finansowej gmin i ich potencjału finansowego, co stanowi z kolei jeden $\mathrm{z}$ wymiernych efektów racjonalnej gospodarki finansowej gminy. Przy czym, jak wynika z analizy trendu, wartość tego wskaźnika w kolejnych latach rosła, i to w przypadku gmin zarówno prowadzących audyt wewnętrzny, jak i nieprowadzących audytu wewnętrznego (tab. 3). W odniesieniu do wskaźnika WDW współczynniki kurtozy i skośności znajdują się na niskim poziomie, co oznacza, że rozkład wyników jest zbliżony do normalnego. Świadczą o tym również relacje, jakie występują między wartościami średnimi, medianą i dominantą wia rys. 1. Ogólnie można stwierdzić, że w rozkładzie występuje raczej asymetria prawostronna (średnia $>$ mediana $>$ dominanta ${ }^{7}$ ), która ulega pewnemu zakłóceniu w 2013 roku. Przesądza o tym wartość współczynnika skośności, który dla tego roku przyjmuje wartość ujemną.

Tabela 3. Wskaźnik udziału dochodów własnych gminy w dochodach budżetu ogółem

\begin{tabular}{|c|c|c|c|c|c|c|}
\hline \multirow{3}{*}{ Lata } & \multicolumn{6}{|c|}{ WDW (\%) } \\
\hline & \multirow{2}{*}{$\begin{array}{c}\text { wartość średnia } \\
\text { dla gmin } \\
\text { z audytem }\end{array}$} & \multirow{2}{*}{$\begin{array}{l}\text { wartość } \\
\text { średnia dla } \\
\text { gmin bez } \\
\text { audytu }\end{array}$} & \multicolumn{4}{|c|}{ dla gmin ogółem } \\
\hline & & & $\begin{array}{l}\text { wartość } \\
\text { średnia }\end{array}$ & $\begin{array}{l}\text { odchylenie } \\
\text { standardowe }\end{array}$ & skośność & kurtoza \\
\hline 2010 & 53,49 & 41,81 & 47,65 & 11,00 & 0,18 & $-0,44$ \\
\hline 2011 & 53,62 & 44,54 & 49,08 & 10,99 & 0,11 & $-0,45$ \\
\hline 2012 & 55,26 & 45,56 & 50,41 & 10,85 & 0,24 & $-0,33$ \\
\hline 2013 & 57,69 & 48,76 & 53,23 & 10,81 & $-0,06$ & $-0,52$ \\
\hline
\end{tabular}

Źródło: opracowanie własne.

Dwa kolejne wskaźniki, tj. udziału dotacji celowych dla gminy w jej dochodach budżetowych ogółem (WDC) i udziału subwencji ogólnej w dochodach budżetu gminy ogółem (WSO), wskazują na stopień uzależnienia budżetu gminnego od budżetu państwa. Im większy udział dotacji celowych z budżetu państwa w budżecie

${ }^{6}$ Wartość dominanty została podana w formie przedziału, w którym najczęściej występuje wartość wskaźnika, ze względu na to, iż w odniesieniu do wartości wskaźników analizy finansowej trudno jest uzyskać kilkakrotnie dokładnie taką samą wartość.

${ }^{7}$ Dla dominanty przyjęte zostały wartości przedziałów, w których znajdowało się najwięcej wyników, ponieważ w żadnym z przypadków nie występowała jedna dominanta (dominanta wielokrotna). 


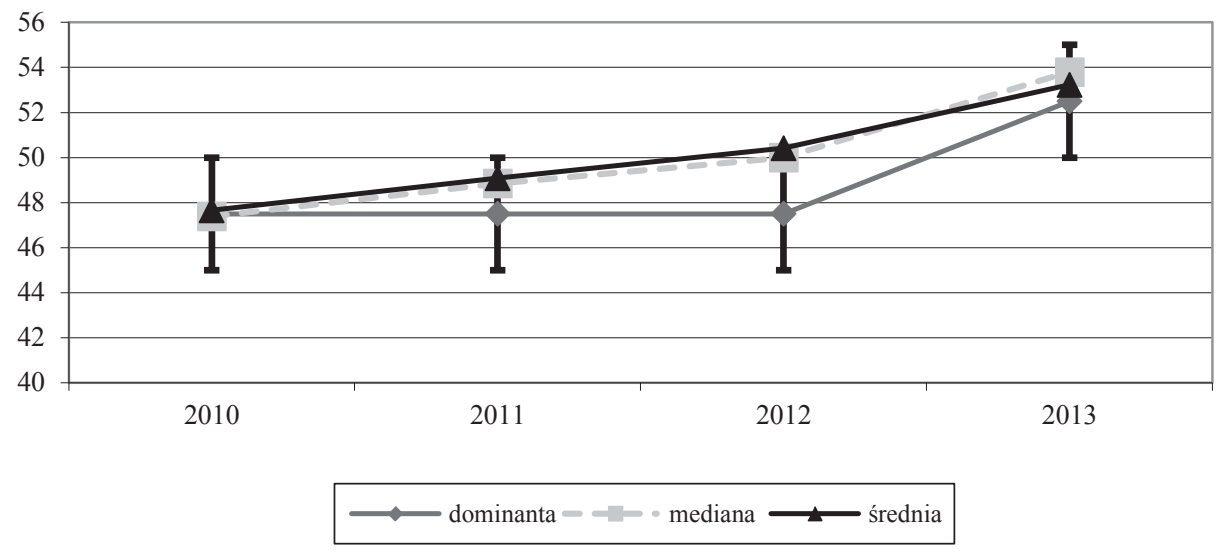

Rys. 1. Wskaźnik udziału dochodów własnych gminy w dochodach budżetu ogółem wartości średnie, środkowe i dominujące

Źródło: opracowanie własne.

gminnym (które cechuje jednostronny i uznaniowy charakter), tym mniejsza samodzielność jednostki np. w określaniu rodzajów zadań, jakie może ona sfinansować (środki pochodzące $\mathrm{z}$ dotacji mogą być wydatkowane wyłącznie na cele określone przez jej dawców $\left.{ }^{8}\right)$. W badanym okresie wskaźnik udziału dotacji celowych dla gmin w ich dochodach budżetowych ogółem (WDC) kształtował się na podobnym poziomie dla gmin, które prowadzą audyt wewnętrzny, jak i nie prowadzą audytu wewnętrznego (tab. 4). W odniesieniu do wskaźnika WDC rozkład wyników zawsze wykazuje asymetrię prawostronną. Oznacza to, że większość uzyskanych wyników ma wartość mniejszą od średniej, o czym świadczą dodatnie wartości współczynnika skośności (tab. 4). Składa się na to fakt, że wśród gmin jest kilka takich, które uzyskują wyniki znacznie wyższe od średniej, natomiast większość jest na poziomie znacznie niższym. Widoczne jest to na wykresach rozrzutu, przy czym wśród gmin prowadzących audyt większość osiąga wyniki poniżej średniej, a wśród gmin nieprowadzących audytu odwrotnie (rys. 3).

Jednak na podstawie tego wskaźnika można uznać, że audyt wewnętrzny w tym przypadku raczej nie miał większego znaczenia dla stopniowego obniżania jego wartości w poszczególnych latach (rys. 2). Ogólną tendencję dotyczącą spadku wartości wskaźnika dla wszystkich analizowanych gmin należy oceniać korzystnie z punktu widzenia zmian $\mathrm{w}$ gospodarce finansowej tych gmin.

\footnotetext{
${ }^{8} \mathrm{~W}$ ten sposób państwo może w pewnym stopniu oddziaływać na JST pod kątem realizacji przez samorząd polityki zgodnej z polityką prowadzoną przez państwo, co w literaturze przedmiotu określa się jako teorię złotych cugli lub zarządzania przez sakiewkę.
} 
Tabela 4. Wskaźnik udziału dotacji celowych dla gmin w ich dochodach budżetowych ogółem w latach 2010-2013

\begin{tabular}{|c|c|c|c|c|c|c|}
\hline \multirow{3}{*}{ Lata } & \multicolumn{6}{|c|}{ WDC (\%) } \\
\hline & \multirow{2}{*}{$\begin{array}{c}\text { wartość } \\
\text { średnia } \\
\text { dla gmin } \\
\text { z audytem }\end{array}$} & \multirow{2}{*}{$\begin{array}{l}\text { wartość } \\
\text { średnia dla } \\
\text { gmin bez } \\
\text { audytu }\end{array}$} & \multicolumn{4}{|c|}{ dla gmin ogółem } \\
\hline & & & $\begin{array}{l}\text { wartość } \\
\text { średnia }\end{array}$ & $\begin{array}{l}\text { odchylenie } \\
\text { standardowe }\end{array}$ & skośność & kurtoza \\
\hline 2010 & 20,11 & 22,68 & 21,40 & 6,11 & 0,14 & $-0,68$ \\
\hline 2011 & 20,33 & 19,21 & 19,77 & 6,52 & 0,46 & 0,31 \\
\hline 2012 & 18,02 & 18,35 & 18,18 & 6,48 & 0,17 & $-0,21$ \\
\hline 2013 & 16,72 & 16,93 & 16,83 & 5,87 & 0,50 & 0,46 \\
\hline
\end{tabular}

Źródło: opracowanie własne.

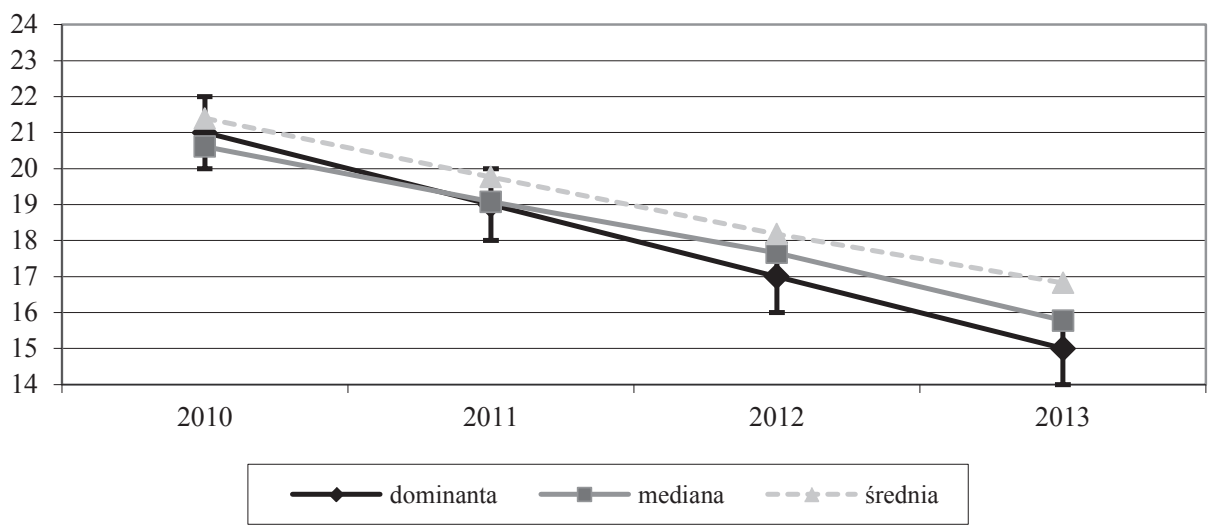

Rys. 2. Wskaźnik udziału dotacji celowych dla gmin w ich dochodach budżetowych ogółem wartości średnie, środkowe i dominujące w latach 2010-2013

Źródło: opracowanie własne.

Wyższy udział subwencji ogólnej w dochodach budżetu gminy ogółem (WSO) informuje również o większym uzależnieniu dochodów gminy od budżetu centralnego $^{9}$, co przekłada się na zmniejszenie możliwości realizacyjnych zadań przez samorząd gminny wraz z ewentualnym ograniczeniem wielkości subwencji (np. wskutek obiektywnych problemów budżetowych państwa). W latach 2010-2013 wskaźnik ten był dużo niższy w gminach, które prowadziły audyt wewnętrzny, w stosunku do tych gmin, w których audytu wewnętrznego nie prowadzono (tab. 5). Sytuację taką należy traktować jako korzystną, a jej występowanie można uznać za przejaw dodatniego oddziaływania audytu wewnętrznego na poprawę gospodarki finanso-

\footnotetext{
${ }^{9} \mathrm{~W}$ przypadku subwencji istnieją bardziej zobiektywizowane kryteria ich przyznawania i mniejsza uznaniowość ze strony państwa aniżeli w przypadku dotacji celowych.
} 

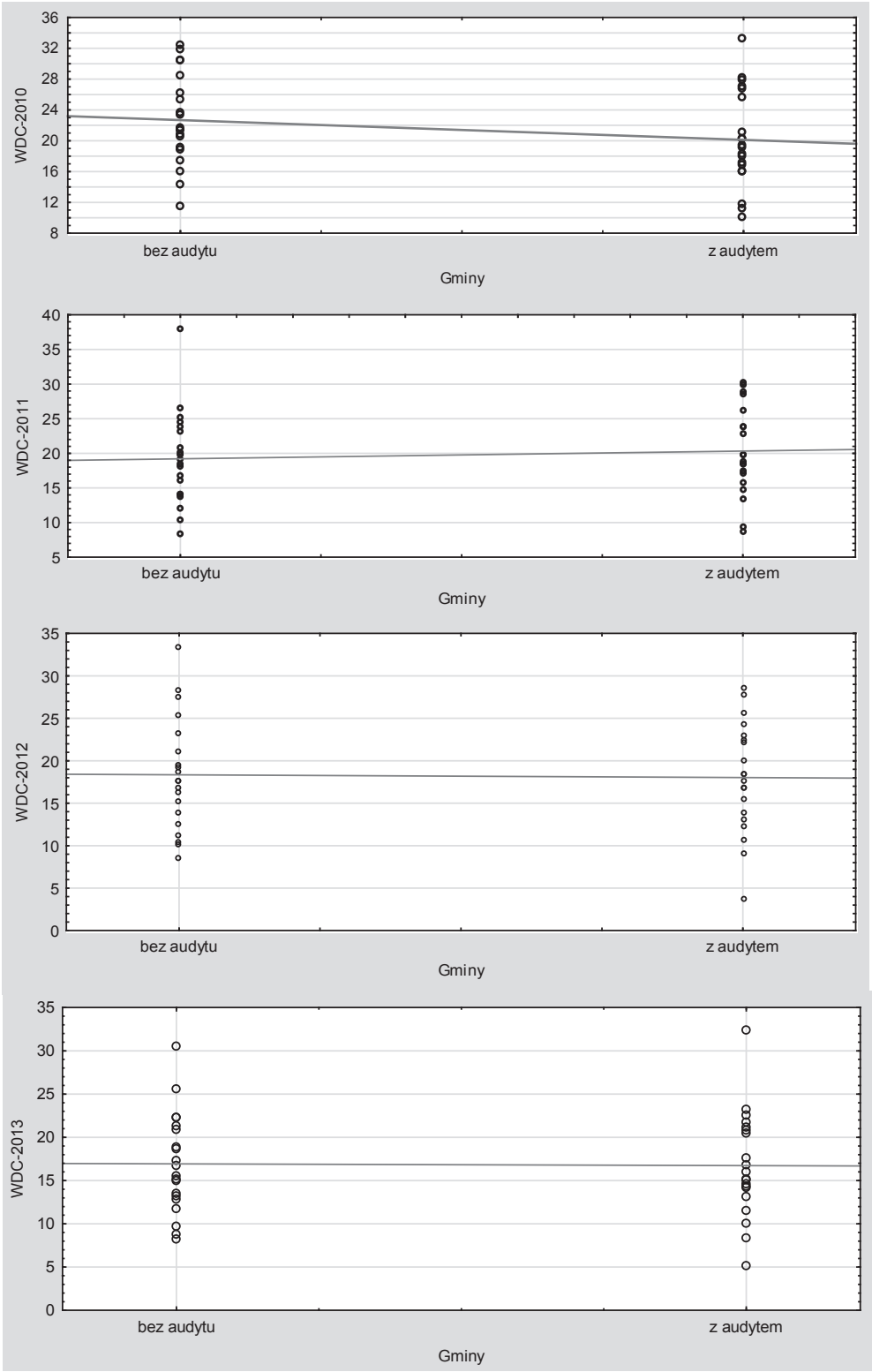

Rys. 3. Wykres rozrzutu wskaźnika WDC w latach 2010-2013

Źródło: opracowanie własne.

wej gmin. Rozkład wyników również w tym przypadku wykazuje asymetrię prawostronną, przy czym występuje tutaj większe zróżnicowanie wyników dla dwóch grup gmin w stosunku do wartości średnich. Wśród gmin prowadzących audyt znaczna 
Tabela 5. Wskaźnik udziału subwencji ogólnej w dochodach budżetu gminy ogółem w latach 2010-2013

\begin{tabular}{|c|c|c|c|c|c|c|}
\hline \multirow{2}{*}{ Lata } & \multicolumn{6}{|c|}{ WSO (\%) } \\
\cline { 2 - 7 } & wartość & \multirow{2}{*}{$\begin{array}{c}\text { wartość } \\
\text { sla gmia }\end{array}$} & \multirow{2}{*}{\begin{tabular}{c} 
średnia dla \\
gmin bez \\
\cline { 4 - 8 }
\end{tabular}} & \multicolumn{4}{|c|}{ dla gmin ogółem } \\
\cline { 4 - 8 } & z audytem & audytu & $\begin{array}{c}\text { wartość } \\
\text { średnia }\end{array}$ & $\begin{array}{c}\text { odchylenie } \\
\text { standardowe }\end{array}$ & skośność & kurtoza \\
\hline 2010 & 26,40 & 35,51 & 30,95 & 8,64 & 0,53 & $-0,06$ \\
\hline 2011 & 26,04 & 36,25 & 31,15 & 8,42 & 0,38 & $-0,42$ \\
\hline 2012 & 26,72 & 36,09 & 31,40 & 8,54 & 0,44 & $-0,18$ \\
\hline 2013 & 25,59 & 34,31 & 29,95 & 7,98 & 0,38 & $-0,10$ \\
\hline
\end{tabular}

Źródło: opracowanie własne.

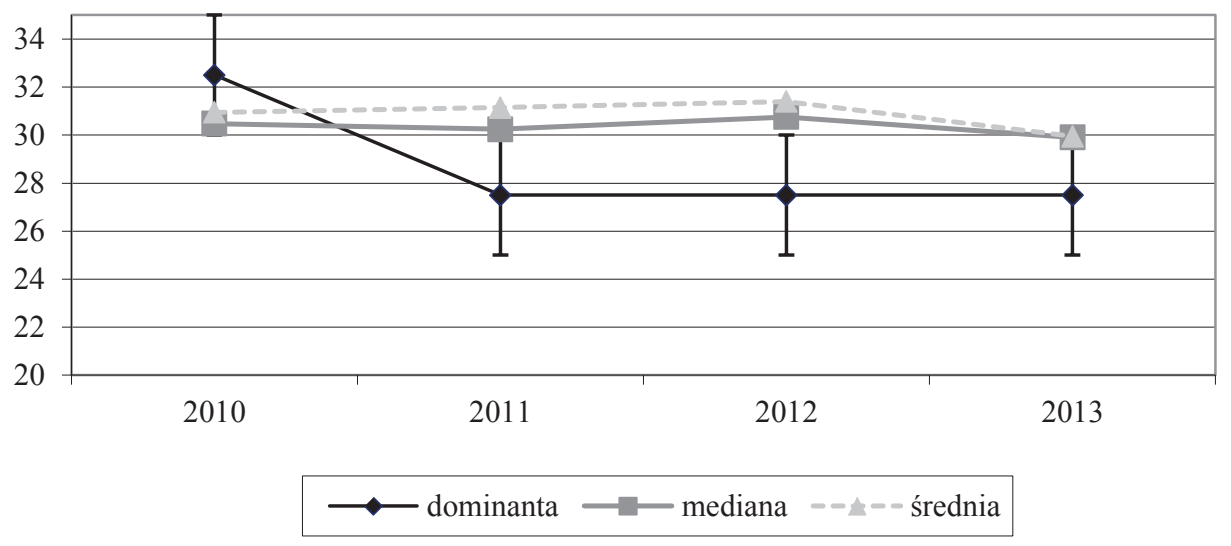

Rys. 4. Wskaźnik udziału subwencji ogólnej w dochodach budżetu gminy ogółem wartości średnie, środkowe i dominujące

Źródło: opracowanie własne.

większość uzyskuje wyniki powyżej średniej, natomiast wśród gmin nieprowadzących audytu odwrotnie.

W celu określenia struktury wydatków gminnych ze względu na podstawowe ich rodzaje (tj. wydatki bieżące i majątkowe) oraz wykazania wpływu tych wydatków na ogólną ich strukturę posłużono się dwoma podstawowymi wskaźnikami: wskaźnikiem ogólnej struktury wydatków majątkowych/wydatków bieżących gminy w wydatkach budżetu ogółem (WWM/WWB). Rodzaj ponoszonych przez samorząd gminny wydatków świadczy o charakterze realizowanych zadań (czy są to zadania bieżące czy inwestycyjne) i pozwala zachować właściwe proporcje między nimi. Analiza udziału poszczególnych rodzajów wydatków w wydatkach budżeto- 

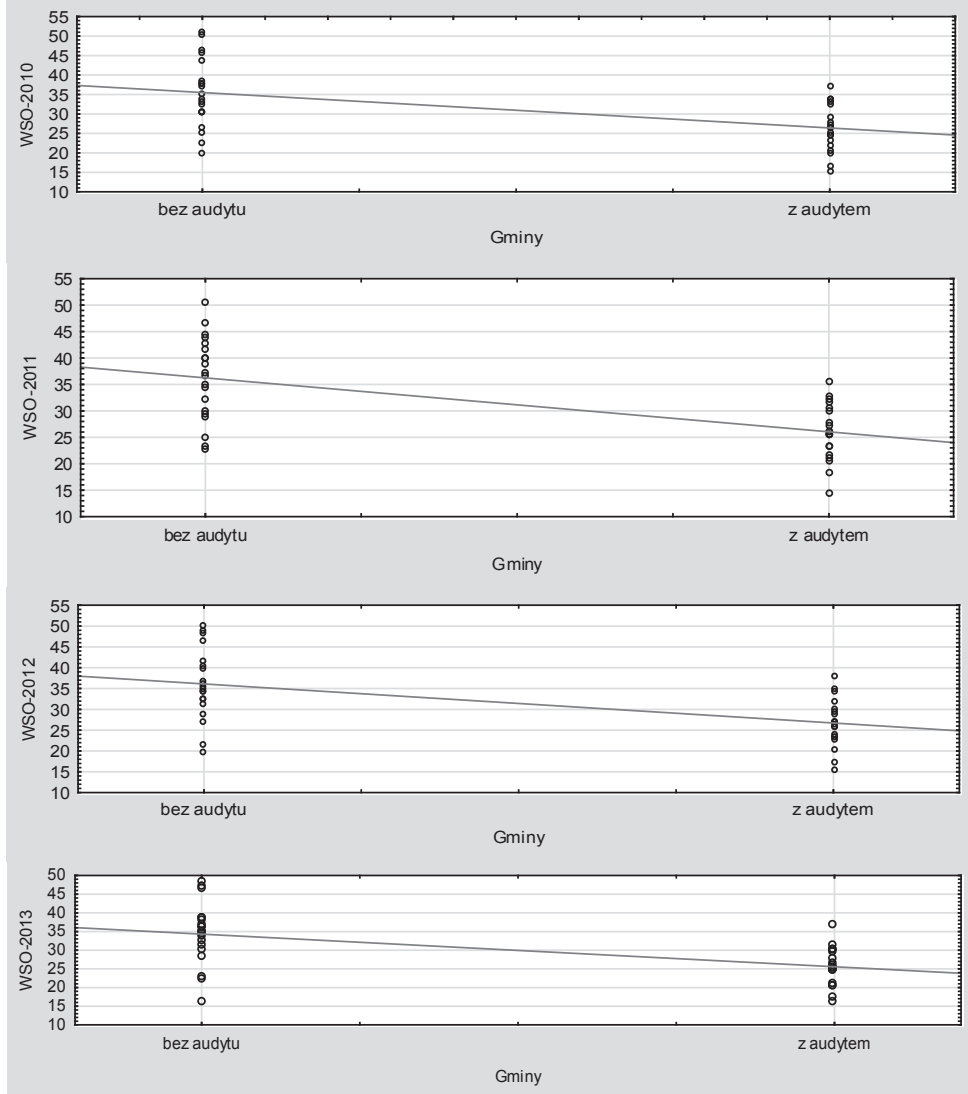

Rys. 5. Wykres rozrzutu wskaźnika WSO w latach 2010-2013

Źródło: opracowanie własne.

wych ogółem daje możliwość wskazania niepożądanych zjawisk polegających np. na zwiększaniu w gminach wydatków na wynagrodzenia kosztem wydatków rzeczowych (inwestycyjnych). Sytuacja korzystna to taka, w której wydatki rzeczowe wykazują tendencję rosnącą (np. wzrasta poziom inwestycji w gminach), co przekłada się na zasobność gminy. Z kolei wzrost wydatków bieżących (np. wydatki na wynagrodzenia i pochodne) świadczyć może o większym nastawieniu na konsumpcję przy mniejszej liczbie dokonywanych w gminie inwestycji.

W analizowanym okresie (lata 2010-2013) obydwa wskaźniki (WWM i WWB) wykazywały niekorzystne trendy dla gospodarki finansowej w gminach poddanych badaniu, zarówno wśród tych, które prowadziły audyt wewnętrzny, jak i tych, które nie prowadzily audytu wewnętrznego (tab. 6 i 7). W kolejnych latach obserwowano stopniowy, jednoznaczny spadek udziału wydatków majątkowych gmin w wydatkach ich budżetów ogółem (WWM), z drugiej strony następował wyraźny wzrost 
udziału wydatków bieżących w ogólnej strukturze wydatków gminnych (WWB). Jednocześnie widoczna jest różnica w wartości wskaźników, a mianowicie WWM jest w każdym z okresów mniejszy dla gmin z audytem, a WWB większy dla tych gmin, choć różnice te nie są znaczne. Ogólnie sytuacja taka nie miała raczej pozytywnego przełożenia na racjonalną gospodarkę finansową badanych gmin.

Analiza statystyk opisowych pokazuje, że dla wskaźnika WWM rozkład wyników cechuje się prawostronną asymetrią, przy czym wśród gmin prowadzących audyt duża ich część jest skoncentrowana wokół wartości nieznacznie niższych od średniej, natomiast wśród gmin nieprowadzących audytu większość znajduje się powyżej średniej. Zupełnie odwrotne zależności występują dla wskaźnika WWB. Wynika to z konstrukcji obu tych wskaźników, które są ze sobą powiązane.

Tabela 6. Wskaźnik ogólnej struktury wydatków majątkowych w wydatkach budżetu ogółem w latach 2010-2013

\begin{tabular}{|c|c|c|c|c|c|c|}
\hline \multirow{3}{*}{ Lata } & \multicolumn{6}{|c|}{ WWM (\%) } \\
\hline & \multirow{2}{*}{$\begin{array}{c}\text { wartość } \\
\text { średnia } \\
\text { dla gmin } \\
\text { z audytem }\end{array}$} & \multirow{2}{*}{$\begin{array}{l}\text { wartość } \\
\text { średnia dla } \\
\text { gmin bez } \\
\text { audytu }\end{array}$} & \multicolumn{4}{|c|}{ dla gmin ogółem } \\
\hline & & & $\begin{array}{l}\text { wartość } \\
\text { średnia }\end{array}$ & $\begin{array}{l}\text { odchylenie } \\
\text { standardowe }\end{array}$ & skośność & kurtoza \\
\hline 2010 & 21,21 & 24,82 & 23,02 & 6,65 & 0,16 & 0,66 \\
\hline 2011 & 19,02 & 19,54 & 19,28 & 7,37 & 0,60 & 0,48 \\
\hline 2012 & 13,64 & 16,20 & 14,92 & 5,54 & 0,38 & 0,15 \\
\hline 2013 & 11,99 & 15,09 & 13,54 & 7,02 & 0,60 & $-0,66$ \\
\hline
\end{tabular}

Źródło: opracowanie własne.
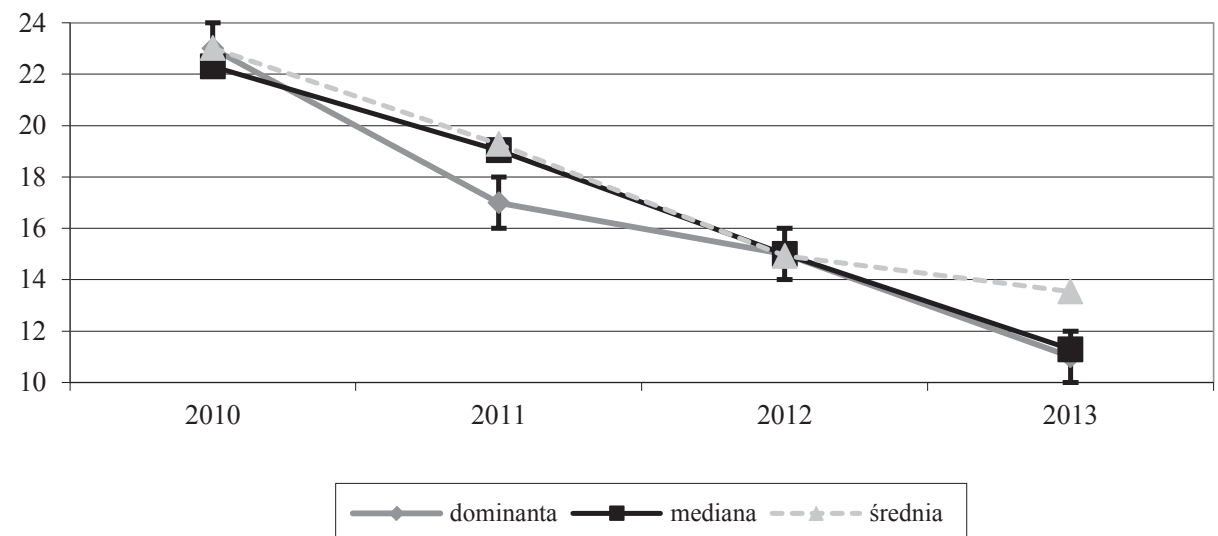

Rys. 6. Wskaźnik ogólnej struktury wydatków majątkowych w wydatkach budżetu ogółem wartości średnie, środkowe i dominujące

Źródło: opracowanie własne. 
Tabela 7. Wskaźnik ogólnej struktury wydatków bieżących gminy w wydatkach budżetu ogółem w latach 2010-2013

\begin{tabular}{|c|c|c|c|c|c|c|}
\hline \multirow{3}{*}{ Lata } & \multicolumn{6}{|c|}{ WWB (\%) } \\
\hline & \multirow{2}{*}{$\begin{array}{c}\text { wartość } \\
\text { średnia } \\
\text { dla gmin } \\
\text { z audytem }\end{array}$} & \multirow{2}{*}{$\begin{array}{l}\text { wartość } \\
\text { średnia dla } \\
\text { gmin bez } \\
\text { audytu }\end{array}$} & \multicolumn{4}{|c|}{ dla gmin ogółem } \\
\hline & & & $\begin{array}{l}\text { wartość } \\
\text { średnia }\end{array}$ & $\begin{array}{l}\text { odchylenie } \\
\text { standardowe }\end{array}$ & skośność & kurtoza \\
\hline 2010 & 78,79 & 75,17 & 76,98 & 6,65 & $-0,16$ & 0,66 \\
\hline 2011 & 80,98 & 80,46 & 80,72 & 7,37 & $-0,60$ & 0,48 \\
\hline 2012 & 86,36 & 83,80 & 85,08 & 5,54 & $-0,38$ & 0,15 \\
\hline 2013 & 87,97 & 84,91 & 86,44 & 7,00 & $-0,59$ & $-0,65$ \\
\hline
\end{tabular}

Źródło: opracowanie własne.

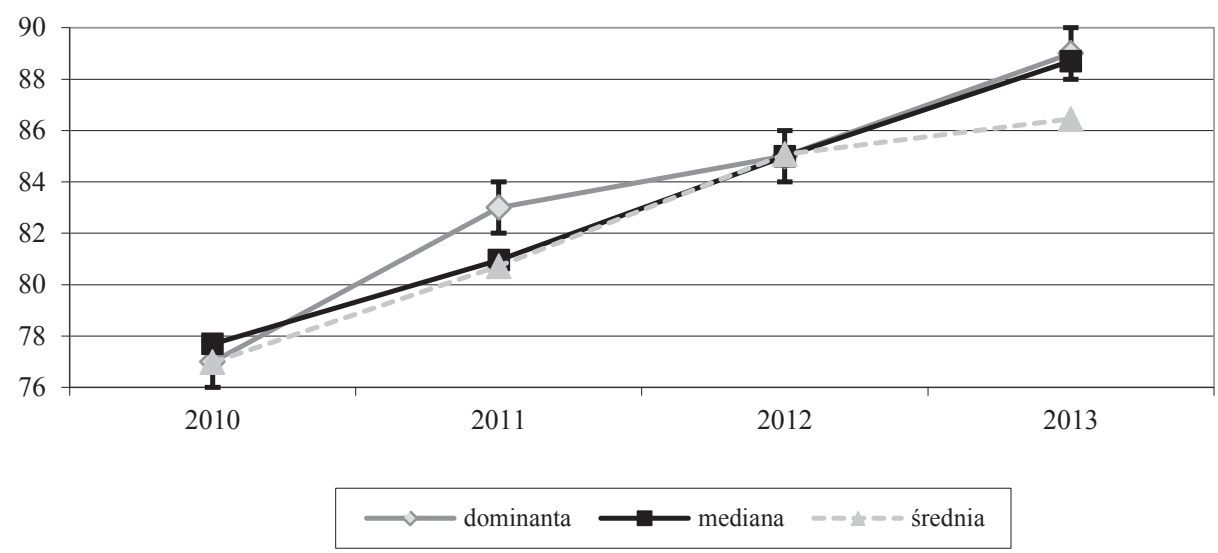

Rys. 7. Wskaźnik ogólnej struktury wydatków bieżących gminy w wydatkach budżetu ogółem wartości średnie, środkowe i dominujące

Źródło: opracowanie własne.

Podstawową relację poziomą między dochodami i wydatkami gminy odzwierciedla wskaźnik pokrycia wydatków ogółem dochodami własnymi jednostki (WWD). Wskaźnik ten obrazuje, na ile dochody własne gminy finansują jej wydatki budżetowe ogółem. Wyższa wartość tego wskaźnika świadczy o większym udziale dochodów własnych w finansowaniu wydatków jednostki, a tym samym wskazuje na większą swobodę (samodzielność) samorządu gminnego w wydatkowaniu środków na realizację zaplanowanych zadań. $\mathrm{W}$ gminach poddanych badaniu w ciągu czterech lat zaobserwowano korzystny wzrost wskaźnika pokrycia wydatków dochodami własnymi gmin, przy czym w przypadku gmin bez audytu dynamika wzrostu mierzona przyrostem bezwzględnym oraz tempem wzrostu jest wyższa. Dystans 

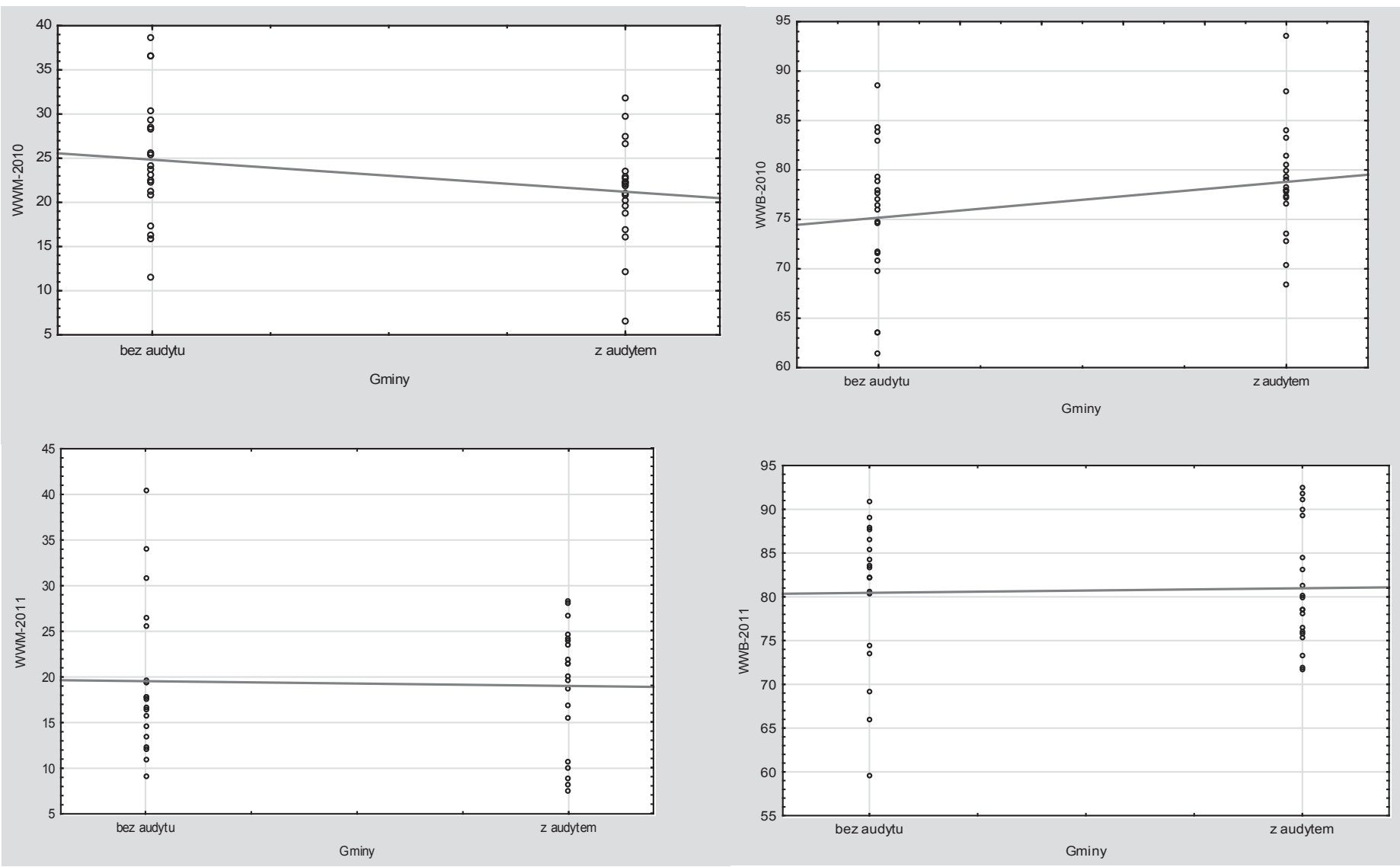

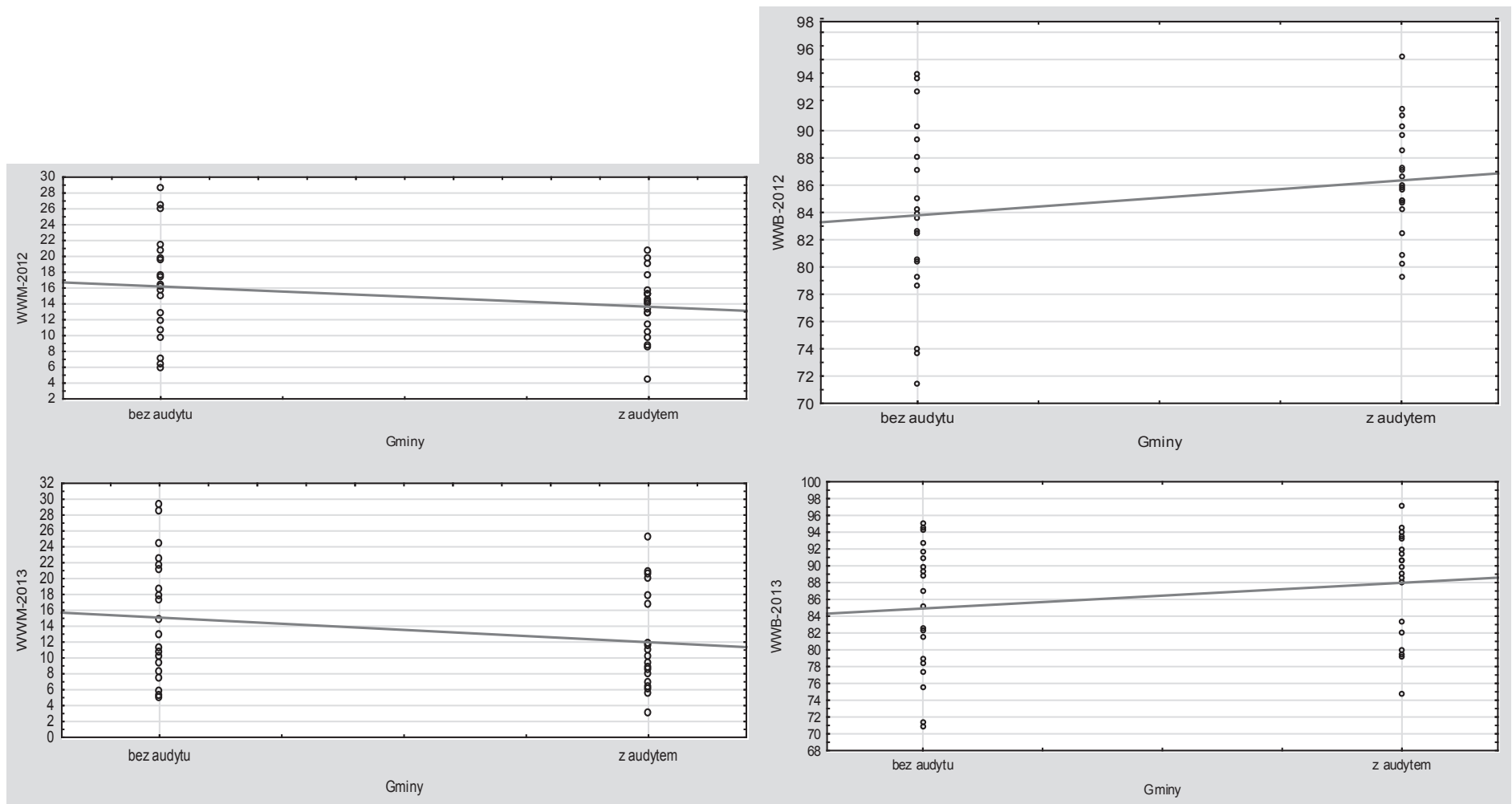

Rys. 8. Wykres rozrzutu wskaźnika WWM i WWB w latach 2010-2013

Źródło: opracowanie własne. 
pomiędzy gminami z audytem i bez audytu zmniejszył się (tab. 8). Można uznać, że audyt wewnętrzny pozostawał w związku z poprawą stanu gospodarki finansowej tych jednostek, czego efektem jest większa samodzielność w wydatkowaniu środków na realizację zadań gminnych wśród gmin z audytem w całym badanym okresie, a gminy bez audytu starają się za nimi nadążać. Rozkład wyników wykazuje asymetrię raczej prawostronną, z wyjątkiem roku 2013 (rys. 9). W latach 2010-2012 wartość wskaźnika dla większości gmin bez audytu znajduje się poniżej średniej, natomiast dla gmin z audytem powyżej. W 2013 roku dla gmin z audytem ta prawidłowość była taka sama, podczas gdy dla gmin bez audytu ich liczba poniżej i powyżej średniej była na zbliżonym poziomie.

Tabela 8. Wskaźnik pokrycia wydatków ogółem dochodami własnymi gminy w latach 2010-2013

\begin{tabular}{|c|c|c|c|c|c|c|}
\hline \multirow{3}{*}{ Lata } & \multicolumn{6}{|c|}{ WWD (\%) } \\
\hline & \multirow{2}{*}{$\begin{array}{c}\text { wartość } \\
\text { średnia } \\
\text { dla gmin } \\
\text { z audytem }\end{array}$} & \multirow{2}{*}{$\begin{array}{l}\text { wartość } \\
\text { średnia dla } \\
\text { gmin bez } \\
\text { audytu }\end{array}$} & \multicolumn{4}{|c|}{ dla gmin ogółem } \\
\hline & & & $\begin{array}{l}\text { wartość } \\
\text { średnia }\end{array}$ & $\begin{array}{l}\text { odchylenie } \\
\text { standardowe }\end{array}$ & skośność & kurtoza \\
\hline 2010 & 53,49 & 41,81 & 47,65 & 11,00 & 0,18 & $-0,44$ \\
\hline 2011 & 53,62 & 44,54 & 49,08 & 10,99 & 0,11 & $-0,45$ \\
\hline 2012 & 55,26 & 45,56 & 50,41 & 10,85 & 0,24 & $-0,33$ \\
\hline 2013 & 57,69 & 48,76 & 53,23 & 10,81 & $-0,06$ & $-0,52$ \\
\hline
\end{tabular}

Źródło: opracowanie własne.

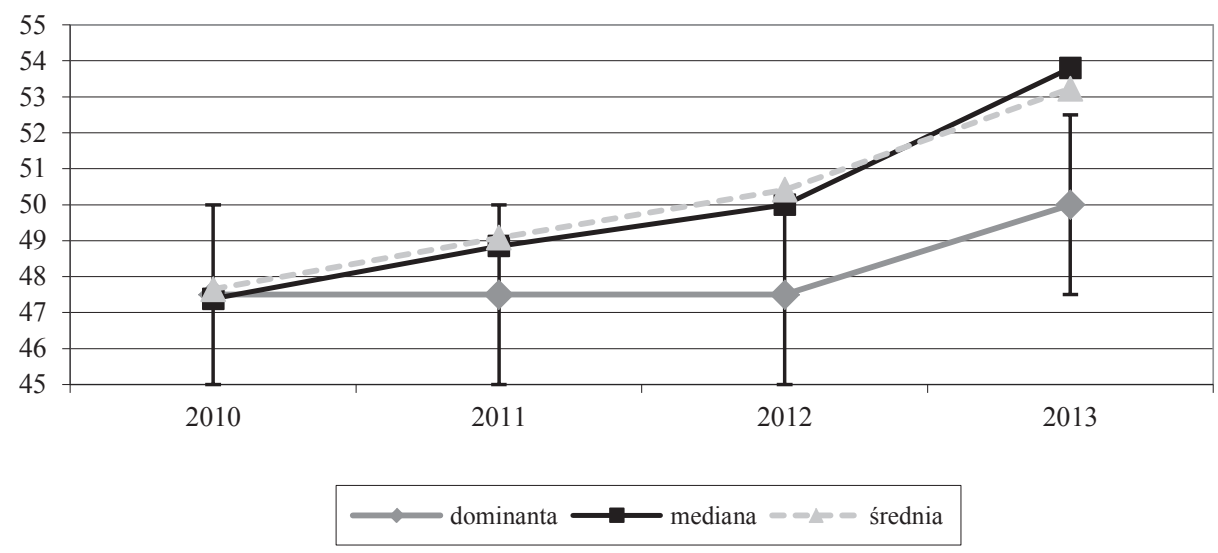

Rys. 9. Wskaźnik pokrycia wydatków ogółem dochodami własnymi gminy wartości średnie, środkowe i dominujące

Źródło: opracowanie własne. 


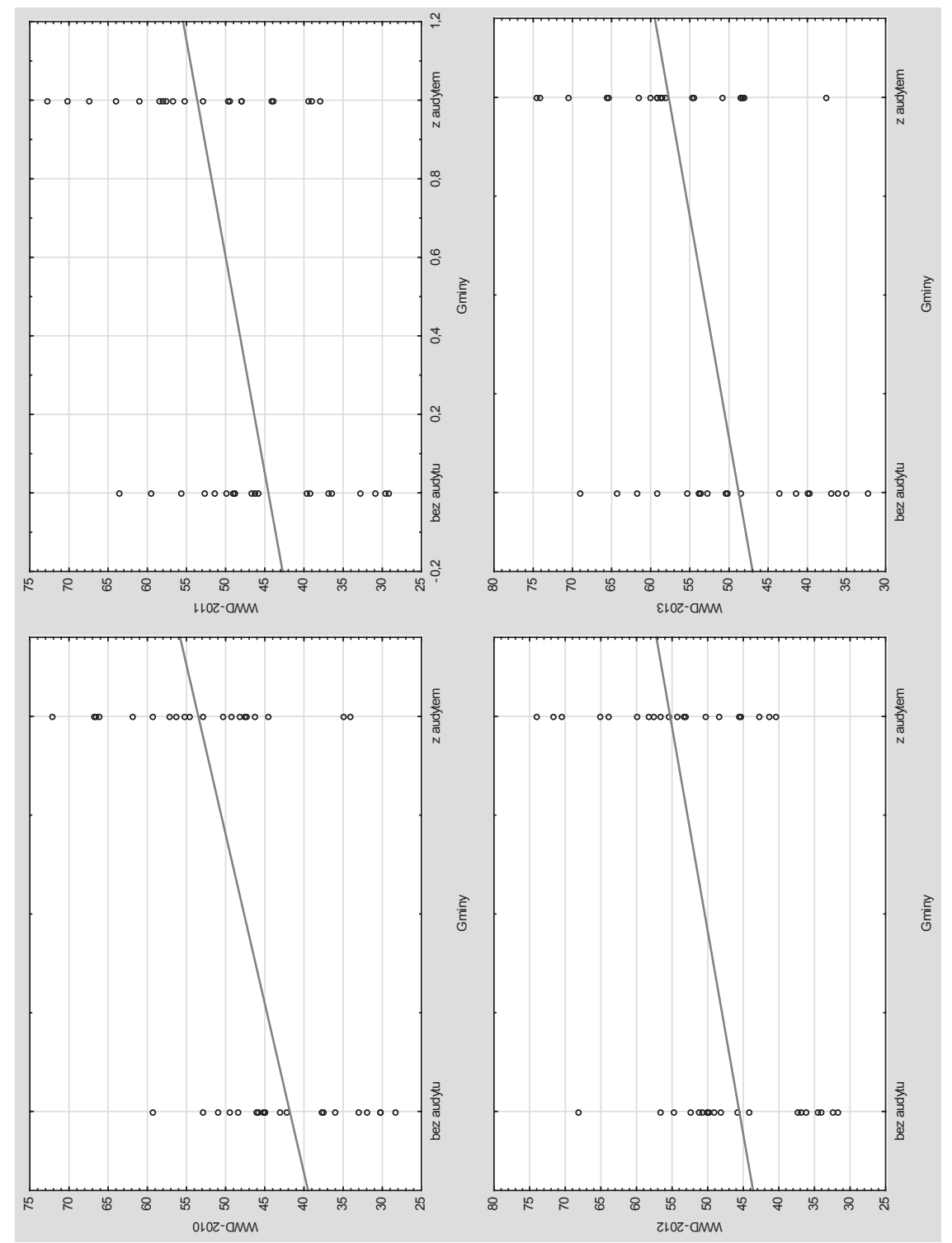


Ze wskaźnikiem pokrycia wydatków ogółem dochodami własnymi jednostki (WWD) koresponduje wskaźnik samodzielności wydatkowej gminy (WSW). Informuje on, w jakim stopniu dana jednostka w pełni i bez ograniczeń decyduje o przeznaczeniu dochodów własnych i subwencji ogólnej na realizowane wydatki. Wyższa wartość tego wskaźnika jest korzystna i świadczy o rzeczywistej swobodzie decyzyjnej jednostki w zakresie wydatkowania dochodów gminnych. W latach 2010-2013 zaobserwowano coroczny wzrost wskaźnika samodzielności wydatkowej w analizowanych gminach, przy czym kształtował się on na podobnym poziomie w jednostkach prowadzących, a także nieprowadzących audytu wewnętrznego (tab. 9). W tym przypadku nie można raczej mówić o ewidentnym związku między audytem wewnętrznym a poprawą tego wskaźnika, choć przeważnie w poszczególnych latach jego wartość była nieznacznie wyższa w gminach z audytem wewnętrznym (tab. 9). W odniesieniu do wskaźnika WSW rozkład wyników jest jednoznacznie lewostronny, co oznacza, że ogólnie większość wyników znajduje się powyżej średniej dla badanej grupy gmin, jednak to gminy $z$ audytem decydują o tej prawidłowości. Większość z nich osiąga bowiem wskaźnik wyższy od średniej, podczas gdy w gminach bez audytu jest odwrotnie. Jednakże średnie dla obu grup są bardzo zbliżone.

Tabela 9. Wskaźnik samodzielności wydatkowej gminy w latach 2010-2013

\begin{tabular}{|c|c|c|c|c|c|c|}
\hline \multirow{3}{*}{ Lata } & \multicolumn{6}{|c|}{ WSW (\%) } \\
\hline & \multirow{2}{*}{$\begin{array}{c}\text { wartość } \\
\text { średnia } \\
\text { dla gmin } \\
\text { z audytem }\end{array}$} & \multirow{2}{*}{$\begin{array}{l}\text { wartość } \\
\text { średnia dla } \\
\text { gmin bez } \\
\text { audytu }\end{array}$} & \multicolumn{4}{|c|}{ dla gmin ogółem } \\
\hline & & & $\begin{array}{l}\text { wartość } \\
\text { średnia }\end{array}$ & $\begin{array}{l}\text { odchylenie } \\
\text { standardowe }\end{array}$ & skośność & kurtoza \\
\hline 2010 & 79,89 & 77,32 & 78,60 & 6,11 & $-0,14$ & $-0,68$ \\
\hline 2011 & 79,67 & 80,79 & 80,23 & 6,52 & $-0,46$ & 0,31 \\
\hline 2012 & 81,98 & 81,65 & 81,82 & 6,49 & $-0,17$ & $-0,21$ \\
\hline 2013 & 83,28 & 83,07 & 83,17 & 5,87 & $-0,50$ & 0,46 \\
\hline
\end{tabular}

Źródło: opracowanie własne.

Informację na temat wielkości zadłużenia gminy w danym roku budżetowym zawiera wskaźnik ogólnego zadłużenia (WZO), który ukazuje relację zobowiązań ogółem jednostki do kwoty dochodów budżetowych ogółem. Analiza wartości tego wskaźnika pozwala udzielić odpowiedzi na pytanie, jaka jest faktyczna zdolność gminy do wywiązywania się ze zobowiązań. Generalnie, jeżeli wartości wskaźnika maleją, jest to korzystne dla jednostki, gdyż wskazuje na mniejsze jej zadłużenie. $\mathrm{Z}$ drugiej jednak strony, rosnący poziom zadłużenia może świadczyć o prowadzeniu przez gminę działalności inwestycyjnej, co przy niskim poziomie zadłużenia jednostki w ogóle jest zjawiskiem pozytywnym.

Należy zauważyć, że $\mathrm{w}$ gminach $\mathrm{z}$ funkcjonującym audytem wewnętrznym w badanym okresie ich zadłużenie było mniejsze aniżeli w gminach bez audytu wewnętrznego (tab. 10). 

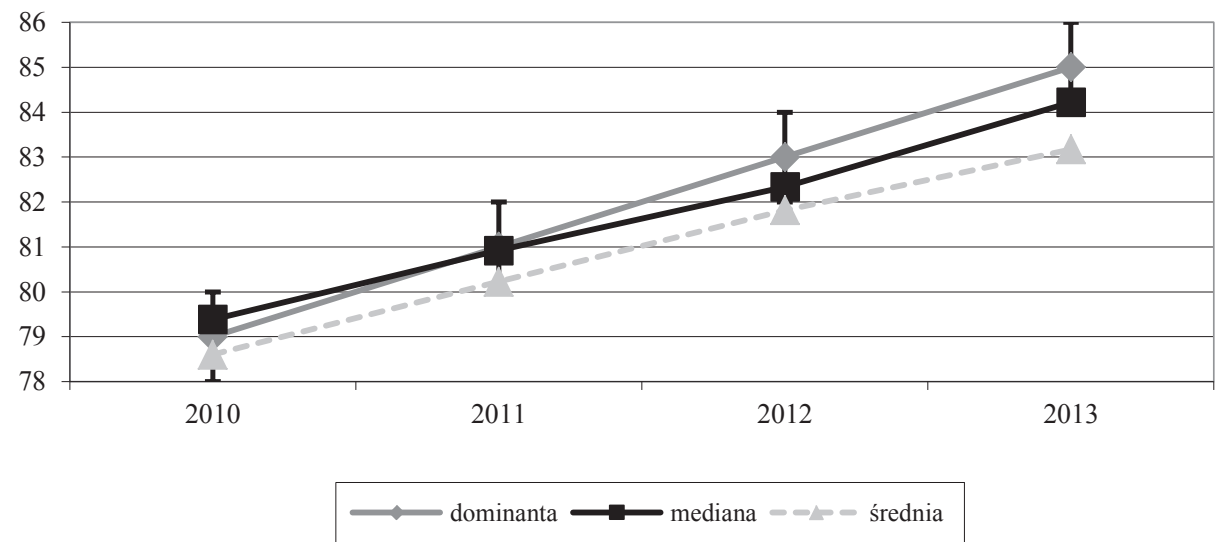

Rys. 11. Wskaźnik samodzielności wydatkowej gminy - wartości średnie, środkowe i dominujące Źródło: opracowanie własne.

Tabela 10. Wskaźnik ogólnego zadłużenia gminy w latach 2010-2013

\begin{tabular}{|c|c|c|c|c|c|c|}
\hline \multirow{3}{*}{ Lata } & \multicolumn{6}{|c|}{ WZO (\%) } \\
\hline & \multirow{2}{*}{$\begin{array}{c}\text { wartość } \\
\text { średnia } \\
\text { dla gmin } \\
\text { z audytem }\end{array}$} & \multirow{2}{*}{$\begin{array}{c}\text { wartość } \\
\text { średnia dla } \\
\text { gmin bez } \\
\text { audytu }\end{array}$} & \multicolumn{4}{|c|}{ dla gmin ogółem } \\
\hline & & & $\begin{array}{l}\text { wartość } \\
\text { średnia }\end{array}$ & $\begin{array}{l}\text { odchylenie } \\
\text { standardowe }\end{array}$ & skośność & kurtoza \\
\hline 2010 & 28,34 & 32,09 & 30,22 & 16,20 & 0,07 & $-0,27$ \\
\hline 2011 & 32,03 & 36,27 & 34,15 & 17,01 & $-0,14$ & $-0,99$ \\
\hline 2012 & 30,18 & 33,91 & 32,05 & 16,81 & $-0,14$ & $-1,09$ \\
\hline 2013 & 28,72 & 32,25 & 30,49 & 15,30 & 0,13 & $-0,64$ \\
\hline
\end{tabular}

Źródło: opracowanie własne.

Analiza statystyk opisowych dla wskaźnika WZO pokazuje, że jest on najbardziej zróżnicowany spośród przedstawionych w niniejszym opracowaniu. Wahania wartości są znaczne i różnokierunkowe. W latach 2010-2012 rozkład wyników jest lewostronny, co oznacza, że większość gmin uzyskuje wyniki wyższe od średniej. Przy czym w większym stopniu efekt ten jest osiągany przez gminy nieprowadzące audytu niż przez gminy go prowadzące. Efekt ten odwraca się w 2013 roku, w którym większość gmin osiąga wartości niższe od średniej, przy czym dotyczy to W większym stopniu gmin z audytem.

Należy w tym miejscu zaznaczyć, że we wszystkich przebadanych gminach wysokość zadłużenia tych jednostek raczej nie wynikała z dokonywanych inwestycji, na co może wskazywać odnotowany spadek udziału gminnych wydatków majątkowych w wydatkach ogółem (WWM). Niższe zadłużenie gmin, które wdrożyły audyt 

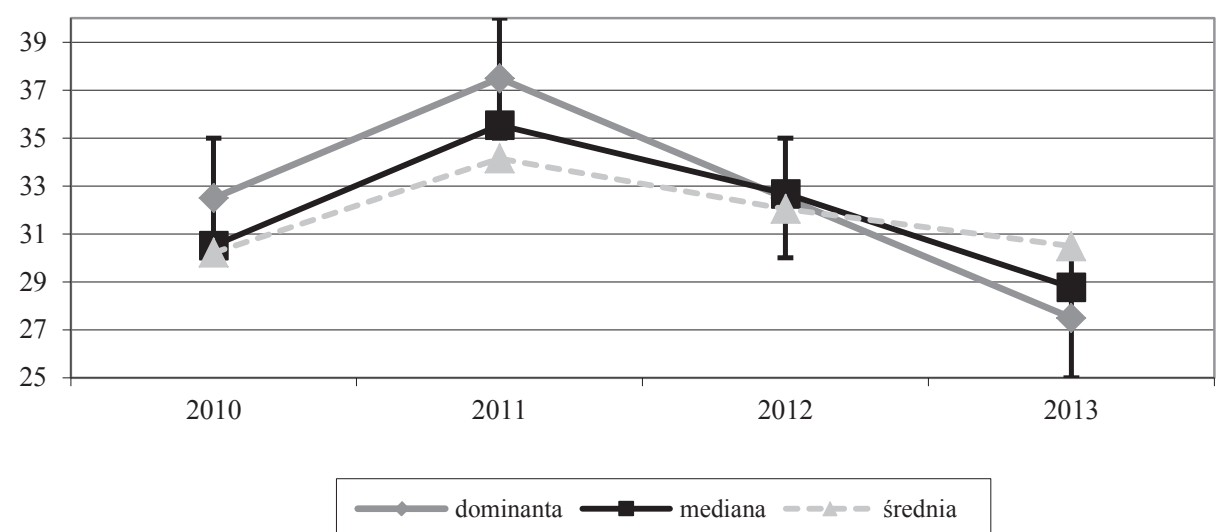

Rys. 12. Wskaźnik ogólnego zadłużenia gminy - wartości średnie, środkowe i dominujące

Źródło: opracowanie własne.

wewnętrzny, może potwierdzać również w tym wypadku jego korzystne oddziaływanie na poprawę gospodarki finansowej tych jednostek.

Z kolei przyjęty do analizy finansowej gmin wskaźnik całkowitej zdolności do rozwoju gminy (WCR) przedstawia w syntetycznym ujęciu jej potencjał rozwojowy i atrakcyjność w związku z możliwościami realizacji zadań nowych i kontynuowaniem tych już rozpoczętych. Wzrost tego wskaźnika świadczyć może o większych, realnych możliwościach rozwojowych gminy, jak również wpływa na pozytywną ocenę jej atrakcyjności, przede wszystkim z punktu widzenia potencjalnych inwestorów i podmiotów lokujących na terenie gminy swoją działalność gospodarczą.

W analizowanych latach 2010-2013 wskaźnik całkowitej zdolności do rozwoju (WCR) był wyższy w gminach, które nie prowadziły audytu wewnętrznego $(16,31 \%)$ niż w gminach z audytem (13,60\%). Sytuacja taka oznaczała, że większym potencjałem rozwojowym dysponowały gminy, w których nie prowadzono audytu wewnętrznego. Można to interpretować w taki sposób, że gminy z działającym audytem w dużej mierze wykorzystały już, i to z pozytywnym skutkiem, swój potencjał rozwojowy dzięki prowadzonej w racjonalny sposób gospodarce finansowej. Wobec tego największe szanse na rozwój stoją przed tymi gminami, które nie wprowadziły audytu wewnętrznego. W tych gminach WCR przedstawia wyższą wartość.

Do statystycznej oceny różnicy między gminami wykorzystana została miara $F$, oparta na nieważonych średnich uzyskanych w obrębie obu grup gmin w kolejnych latach. Postawiona na wstępie badania hipoteza brzmiała: Między gminami prowadzącymi audyt wewnętrzny a gminami nieprowadzącymi audytu występują różnice w zakresie poszczególnych wskaźników finansowych. Wartości statystyki $F$ w odniesieniu do poszczególnych wskaźników finansowych zawarte zostały w tab. 11. 
Tabela 11. Wartość statystyki $F$ dla poszczególnych wskaźników

\begin{tabular}{|l|c|c|}
\hline $\begin{array}{c}\text { Wskaźnik } \\
\text { finansowy }\end{array}$ & Wartość statystyki F & $\begin{array}{c}\text { Poziom istotności } \\
\text { statystycznej } p\end{array}$ \\
\hline WDW & 32,727 & 0,000000 \\
\hline WDC & 14,2634 & 0,000000 \\
\hline WSO & 16,3 & 0,012524 \\
\hline WWM & 22,9307 & 0,000000 \\
\hline WWB & 22,89 & 0,000000 \\
\hline WWD & 32,727 & 0,000000 \\
\hline WSW & 14,262 & 0,000000 \\
\hline WZO & 5,6597 & 0,001191 \\
\hline
\end{tabular}

Źródło: opracowanie własne.

Dla wszystkich analizowanych wskaźników wartość statystyki $F$ była dość wysoka, a odpowiadające im wartości prawdopodobieństwa empirycznego $p$ bardzo niskie (mniejsze od poziomu istotności $p=0,05$ ), co oznacza, że na przyjętym poziomie istotności $(p=5 \%)$ należy odrzucić hipotezę zerową w odniesieniu do wszystkich analizowanych zmiennych. Zatem zarejestrowane różnice między gminami są istotne statystycznie.

\section{Analiza zależności międzywskaźnikowych dla gmin}

$\mathrm{Na}$ podstawie analizy danych finansowych możliwe było wyodrębnienie określonych relacji (zależności) pomiędzy przyjętymi wskaźnikami. Do tego celu posłużył wskaźnik korelacji $r$-Pearsona. A mianowicie w gminach prowadzących audyt wewnętrzny w obszarze gospodarki finansowej stwierdzono wysoką, jednokierunkową zależność pomiędzy udziałem dochodów własnych gmin w dochodach ogółem (WDW) a ich samodzielnością wydatkową (WSW). Wyższy udział dochodów własnych $\mathrm{w}$ dochodach gmin ogółem pozostawał w związku z większą ich samodzielnością wydatkową i większą racjonalnością gospodarowania. Przy czym zauważyć należy, że zależność ta była zdecydowanie większa w przypadku gmin, w których prowadzony był audyt wewnętrzny. Współczynniki korelacji dla poszczególnych lat przedstawione zostały w tab. 12 .

Natomiast w przypadku relacji pomiędzy udziałem dochodów własnych gmin (WDW) a udziałem dotacji ogółem lub subwencji ogólnych w dochodach budżetów gmin ogółem (WDC lub WSO) stwierdzono wysoką zależność odwrotną, która była silniejsza dla gmin z audytem wewnętrznym. Oznacza to, że w jednostkach tych w miarę wzrostu udziału dochodów własnych $\mathrm{w}$ dochodach budżetowych ogółem zmniejszała się rola dotacji celowych lub subwencji ogólnych z budżetu państwa. Sytuacja taka była korzystna z punktu widzenia racjonalnej gospodarki finansowej. 
Tabela 12. Współczynnik korelacji dla wskaźników WSW i WDW, $p<0,05$

\begin{tabular}{|c|c|c|}
\hline \multirow{2}{*}{ Lata } & \multicolumn{2}{|c|}{ Współczynnik $r$} \\
\cline { 2 - 3 } & $\begin{array}{c}\text { gminy } \\
\text { z audytem }\end{array}$ & $\begin{array}{c}\text { gminy } \\
\text { bez audytu }\end{array}$ \\
\hline 2010 & 0,855948 & $0,317028^{*}$ \\
\hline 2011 & 0,902017 & 0,607608 \\
\hline 2012 & 0,852291 & 0,503637 \\
\hline 2013 & 0,878958 & 0,635382 \\
\hline
\end{tabular}

$* p>0,05$ czyli nieistotne statystycznie

Źródło: opracowanie własne.

Tabela 14. Współczynnik korelacji dla wskaźników WSO i WSW, $p<0,05$

\begin{tabular}{|c|c|c|}
\hline \multirow{2}{*}{ Lata } & \multicolumn{2}{|c|}{ Współczynnik $r$} \\
\cline { 2 - 3 } & $\begin{array}{c}\text { gminy } \\
\text { z audytem }\end{array}$ & $\begin{array}{c}\text { gminy } \\
\text { bez audytu }\end{array}$ \\
\hline 2010 & $-0,430274^{*}$ & $0,367141^{*}$ \\
\hline 2011 & $-0,540216$ & $0,088467^{*}$ \\
\hline 2012 & $-0,365382^{*}$ & $0,215834^{*}$ \\
\hline 2013 & $-0,436148^{*}$ & $-0,105715^{*}$ \\
\hline
\end{tabular}

$* p>0,05$, czyli nieistotne statystycznie

Źródło: opracowanie własne. dla wskaźników WDC i WWD, $p<0,05$

\begin{tabular}{|c|c|c|}
\hline \multirow{2}{*}{ Lata } & \multicolumn{2}{|c|}{ Współczynnik $r$} \\
\cline { 2 - 3 } & $\begin{array}{c}\text { gminy } \\
\text { z audytem }\end{array}$ & $\begin{array}{c}\text { gminy } \\
\text { bez audytu }\end{array}$ \\
\hline 2010 & $-0,855954$ & $-0,317111^{*}$ \\
\hline 2011 & $-0,902009$ & $-0,607604$ \\
\hline 2012 & $-0,852298$ & $-0,503675$ \\
\hline 2013 & $-0,878922$ & $-0,635416$ \\
\hline
\end{tabular}

$* p>0,05$, czyli nieistotne statystycznie

Źródło: opracowanie własne.
Tabela 16. Współczynnik korelacji

Tabela 13. Współczynnik korelacji

dla wskaźników WDC i WDW, $p<0,05$

\begin{tabular}{|c|c|c|}
\hline \multirow{2}{*}{ Lata } & \multicolumn{2}{|c|}{ Współczynnik $r$} \\
\cline { 2 - 3 } & $\begin{array}{c}\text { gminy } \\
\mathrm{z} \text { audytem }\end{array}$ & $\begin{array}{c}\text { gminy } \\
\text { bez audytu }\end{array}$ \\
\hline 2010 & $-0,855954$ & $-0,317111^{*}$ \\
\hline 2011 & $-0,902009$ & $-0,607604$ \\
\hline 2012 & $-0,852298$ & $-0,503675$ \\
\hline 2013 & $-0,878922$ & $-0,635416$ \\
\hline
\end{tabular}

$* p>0,05$, czyli nieistotne statystycznie

Źródło: opracowanie własne.

Tabela 15. Współczynnik korelacji dla wskaźników WSO i WWD, $p<0,05$

\begin{tabular}{|c|c|c|}
\hline \multirow{2}{*}{ Lata } & \multicolumn{2}{|c|}{ Współczynnik $r$} \\
\cline { 2 - 3 } & $\begin{array}{c}\text { gminy } \\
\mathrm{z} \text { audytem }\end{array}$ & $\begin{array}{c}\text { gminy } \\
\text { bez audytu }\end{array}$ \\
\hline 2010 & $-0,835043$ & $-0,765790$ \\
\hline 2011 & $-0,850571$ & $-0,737369$ \\
\hline 2012 & $-0,798314$ & $-0,734851$ \\
\hline 2013 & $-0,812506$ & $-0,835040$ \\
\hline
\end{tabular}

$* p>0,05$, czyli nieistotne statystycznie

Źródło: opracowanie własne.

Analiza relacji między wielkością udziału subwencji ogólnych w dochodach budżetowych gmin (WSO) a ich samodzielnością wydatkową (WSW), jak również stopniem pokrycia wydatków ogółem dochodami własnymi (WWD) zwróciła uwagę na odwrotne zależności pomiędzy wartościami tych wskaźników, które były znacznie wyższe dla gmin audytowanych. Oznacza to, że w sytuacji kiedy wzrastał udział subwencji ogólnych w dochodach budżetowych, zmniejszała się samodzielność wydatkowa gmin i stopień pokrycia wydatków dochodami własnymi. Niestety współczynniki te były w przeważającej części nieistotne statystycznie, jeśli chodzi o zależność WSO i WSW. 
Podobna sytuacja miała miejsce przy badaniu relacji udziału dotacji celowych ogółem w dochodach budżetowych gmin (WDC) do stopnia pokrycia wydatków ogółem dochodami własnymi (WWD). Również w tym przypadku zaobserwowano odwrotną zależność pomiędzy analizowanymi wskaźnikami, która była silniejsza $\mathrm{w}$ gminach z prowadzonym audytem wewnętrznym gospodarki finansowej.

\section{Zakończenie}

Na podstawie przeprowadzonych badań własnych, dotyczących województwa opolskiego, opierając się na analizie wskaźnikowej sprawozdań z realizacji budżetów samorządowych oraz analizie porównawczej gmin audytowanych i nieprowadzących audytu wewnętrznego, dokonano próby oceny funkcjonowania audytu wewnętrznego jako instrumentu wspomagającego racjonalną gospodarkę finansową JST. Odniesiono się w niej do miejsca audytu w systemie działań ukierunkowanych na poprawę samorządowej gospodarki finansowej, jak również jego znaczenia jako instrumentu wspomagającego racjonalną gospodarkę finansową.

Dzięki analizie wybranych wskaźników finansowych badanych JST stwierdzono, że lepsze wartości tych wskaźników w jednostkach, w których prowadzony był audyt wewnętrzny (w porównaniu z jednostkami nieaudytowanymi), mogą świadczyć o korzystnym oddziaływaniu audytu na poprawę gospodarki finansowej. Dotyczy to przede wszystkim wskaźników obrazujących zasobność, potencjał i bezpieczeństwo finansowe JST. Analizę wskaźnikową przeprowadzono przede wszystkim pod kątem: struktury dochodów i wydatków samorządowych, pokrycia wydatków osiąganymi dochodami, samodzielności wydatkowej jednostki, ogólnego jej zadłużenia i całkowitej zdolności do rozwoju. Pozytywny efekt potwierdziła analiza statystyczna tych zależności. Zgodnie z nią gminy prowadzące audyt wewnętrzny uzyskiwały istotne statystycznie wskaźniki na bardziej pożądanym poziomie niż gminy nieprowadzące tego audytu.

Fakt ten stanowi wyraźną przesłankę do promowania wśród JST analizy ekonomicznej jako narzędzia oceny efektywności i skuteczności działania. Ponieważ badanie miało charakter regionalny (województwo opolskie) i objęło swoim zakresem wszystkie jednostki zobowiązane do prowadzenia audytu wewnętrznego, wskazane byłoby rozszerzenie próby badawczej na inne regiony. Miałoby to duży walor aplikacyjny, gdyż przeprowadzenie analogicznych badań w skali całego kraju byłoby dobrym punktem wyjścia dla ustalenia (za przykładem praktyki przedsiębiorstw) pożądanych wartości poszczególnych wskaźników, których przekroczenie byłoby wyraźnym sygnałem do podjęcia działań korygujących lub naprawczych. Natomiast sam fakt, iż jednostki, w których prowadzony jest audyt, uzyskują wyższe wartości właściwie dla większości kategorii wskaźników, powinien skłonić kierowników jednostek, które nie prowadzą audytu, do rozważenia zasadności jego wprowadzenia. Uzyskane wyniki badania dają bowiem jednoznaczny argument ekonomiczny, a nie tylko formalny przemawiający za prowadzeniem audytu wewnętrznego w JST. 


\section{Literatura}

Dudycz T., Wrzosek S., 2000, Analiza finansowa. Problemy metodyczne w ujęciu praktycznym, Wydawnictwo Akademii Ekonomicznej im. O. Langego we Wrocławiu, Wrocław.

Dylewski M., 2003, Narzędzia analizy w ocenie plynności finansowej jednostek samorzadu terytorialnego, [w:] Finanse, bankowość i ubezpieczenia wobec procesów globalizacji, t. 3, Wydawnictwo Gdańskiej Akademii Bankowej, Gdańsk-Jurata.

Dylewski M., Filipiak B., Gorzałczyńska-Koczkodaj M., 2004, Analiza finansowa w jednostkach samorzadu terytorialnego, Municipium, Warszawa.

Dylewski M., Filipiak B., Gorzałczyńska-Koczkodaj M., 2010, Metody analityczne w działalności jednostek podsektora samorzadowego, Difin, Warszawa.

Filipiak B., 2011, Finanse samorządowe. Nowe wyzwania bieżace i perspektywiczne, Difin, Warszawa. Owsiak S., 2005, Finanse publiczne. Teoria i praktyka, Wydawnictwo Naukowe PWN, Warszawa.

Ustawa z dnia 13 listopada 2003 r. o dochodach jednostek samorządu terytorialnego, Dz.U., nr 203, poz. 1966 ze zm.

Ustawa z dnia 27 sierpnia 2009 r. o finansach publicznych, Dz.U., nr 157, poz. 1240 ze zm. 